\title{
Kelas Sosial Dan Pembelajaran Matematika
}

\author{
${ }^{*}$ Meri Fuji Siahaan1, Yubali Ani ${ }^{2}$ \\ 1,2Fakultas Ilmu Pendidikan, Universitas Pelita Harapan,Indonesia
}

\author{
A R T I C L E I N F O \\ Article history: \\ Received 10 November \\ 2018 \\ Received in revised form \\ 09 December 2018 \\ Accepted 15 January 2019 \\ Available online 25 \\ February 2019

\section{Kata Kunci: \\ pengalaman belajar \\ kurikulum, kelas sosial \\ Keywords: \\ learning experiences, \\ curriculum, social class.}

\begin{abstract}
A B S T R A K
Materi pengajaran, tingkat kompetensi, dan proses pembelajaran adalah bagian terpenting dari kurikulum yang standarnya diatur dalam peraturan pemerintah Indonesia nomor 19 tahun 2005 tentang standar pendidikan nasional. Namun, siswa dengan latar belakang sosial ekonomi terpapar dengan kurikulum matematika yang berbeda dan pengalaman yang condong. Pembelajaran matematika dianggap sebagai pembelajaran yang sulit dan menyeramkan oleh sebagaian siswa. Penelitian ini meneliti kurikulum matematika di tiga sekolah dasar dengan latar belakang sosial ekonomi yang berbeda. Tujuan dari penelitian ini difokuskan pada memeriksa materi matematika dan proses pembelajaran. Kelas sosial dalam penelitian ini diidentifikasi dari tingkat pendapatan orang tua. Studi kasus kualitatif digunakan dalam penelitian ini. Siswa dan guru melakukan interview, dilanjutkan dengan diskusi kelompok terarah dan dokumentasi adalah teknik yang digunakan untuk mengumpulkan data. Data dianalisis dengan mengelompokkan katakata kunci dan mengembangkan tema. Data menunjukkan bahwa ada
\end{abstract} pengetahuan matematika yang berbeda diajarkan di ketiga sekolah serta pedagogi matematika yang berbeda diterapkan oleh guru.

\begin{abstract}
A B S T R A C T
Instructional material, competence level and learning process are parts of curriculum of which standards are regulated in Indonesian government's regulation number 19, 2005 about national education standards. However, students with social economic background are exposed with different mathematic curriculum and leaning experiences. This research examined mathematic curriculum in three elementary schools with different social economic background. The purpose of this research focused on examining the mathematic materials and the learning process. The social class in this research was identified from income level of parents. Qualitative case study was used in this research. Interviu students and teachers, focus group discussion and documentation were techniques used to collect the data. The data were analyzed by categorizing key words and developing themes. The data revealed that there were different mathematic knowledge taught in those three schools as well as different mathematic pedagogy implemented by the teachers.
\end{abstract}

\section{Pendahuluan}

Undang - Undang Dasar tahun 1945 pasal 31 ayat 1 menyebutkan bahwa setiap warga negara berhak mendapat pendidikan. Ini berarti bahwa setiap warga negara Indonesia tanpa terkecuali mendapatkan kesempatan mengenyam pendidikan. Keadilan dalam mengenyam pendidikan ditegaskan pada sila ke lima Pancasila yaitu keadilan sosial bagi seluruh rakyat Indonesia. Pemerintah mengatur standar pendidikan nasional untuk mencapai keadilan sosial pada Peraturan Pemerintah Republik Indonesia nomor 19 tahun 2005 tentang Standar Pendidikan Nasional tentang Standar Nasional Pendidikan. Peraturan Pemerintah ini memberikan pengaturan standar kurikulum nasional di antaranya tentang standar isi dan standar proses. Standar isi adalah ruang lingkup materi dan tingkat kompetensi yang dituangkan dalam kriteria tentang kompetensi tamatan, kompetensi bahan kajian, kompetensi mata pelajaran, dan silabus pembelajaran yang harus dipenuhi oleh peserta didik pada jenjang dan jenis pendidikan tertentu. Sedangkan standar proses adalah standar nasional pendidikan yang berkaitan 
dengan pelaksanaan pembelajaran pada satu satuan pendidikan untuk mencapai standar kompetensi lulusan.

Meskipun pemerintah telah mengatur standar kurikulum nasional, ruang lingkup materi, tingkat kompetensi dan pelaksanaan pembelajaran pada beberapa sekolah di Indonesia tidak sesuai dengan standar kurikulum yang telah ditetapkan pemerintah pada Peraturan Pemerintah Republik Indonesia nomor 19 tahun 2005 tentang Standar Pendidikan Nasiona Pada umumnya sekolah-sekolah yang jauh dari standar kurikulum pemerintah adalah sekolah-sekolah yang berlatar belakang kelas sosial bawah. Kelas sosial ini dipengaruhi oleh karena tingkat gaji atau pemasukan orang tua siswa. Kata kurikulum berasal dari Bahasa latin Curriculae yang artinya jarak yang harus ditempuh oleh seorang pelari Hamalik (2009) dan dipergunakan pada dunia olahraga pada zaman Yunani kuno(Sanjaya, 2008).

Istilah kurikulum kemudian digunakan dalam dunia pendidikan dan ditafsirkan secara berbeda oleh para ahli pendidikan. Walaupun penafsiran para ahli berbeda, namun secara umum menjelaskan kurikulum sebagai suatu perencanaan, materi pembelajaran dan pengalaman belajar. Menurut Rusman, (2009) kurikulum merupakan perencanaan yang mencakup tujuan, isi, dan bahan pelajaran serta metode yang dipergunakan dalam kegiatan pembelajaran untuk mencapai tujuan pendidikan tertentu. Hamalik, (2009) menafsirkan kurikulum berdasarkan fokus dari kurikulum tersebut. Pertama adalah kurikulum yang memuat isi dan materi pelajaran. Kurikulum ini berfokus pada sejumlah mata pelajaran yang ditempuh oleh siswa. Kurikulum jenis yang kedua adalah sebagai rencana pembelajaran. Kurikulum ini difokuskan sebagai suatu program pendidikan untuk membelajarakan siswa. Kurikulum sebagai pengalaman belajar berfokus pada kegiatan-kegiatan kurikulum di dalam dan di ruang kelas.

Hill (1999) memberikan argumen bahwa perbedaan kelas sosial berpengaruh terhadap pendidikan yang dialami oleh golongan tertentu termasuk pengalaman pembelajaran dan ruang lingkup materi yang diperoleh terlepas dari standar pendidikan nasional yang dikeluarkan oleh pemerintah. Anyon (1981) melalui penelitian studi kasus di 5 Sekolah Dasar yang berlatar belakang kelas sosial yang berbeda menemukan perbedaan pengetahuan yang terima oleh siswa dan proses pelaksanaan kurikulum pada kelima sekolah tersebut. Senada dengan Hill (1999) dan Anyon (1981), Huebner, E. S., dan Diener (2008) menguraikan dengan rinci bahwa lingkungan pendidikan dipengaruhi oleh sumber keuangan suatu sekolah. Lingkungan fisik yang merupakan aspek pertama dari lingkungan pendidikan yang mencakup buku teks, media, perlengkapan bahkan arsitek dari gedung sekolah dipengaruhi oleh sumber modal sekolah. Aspek kedua yaitu bahasa dan simbol yang dipergunakan antara siswa dan guru ditentukan oleh lingkungan fisik yang dipergunakan seperti buku teks. Aspek yang ketiga dari lingkungan pendidikan adalah perilaku dari siswa, guru dan orang-orang yang ada pada lingkunga tersebut, yang juga dipengaruhi oleh sumber keuangan $(\mathrm{Au}, 2012)$.

Kelas sosial menentukan kebijakan-kebijakan pendidikan, sumber-sumber pembelajaran yang tersedia seperti buku teks dan perpustakaan, dan organisasi sekolah, kualitas dan distribusi beban kerja guru serta keberadaan program-program sekolah (Banks, 2012). Tipe yang terakhir adalah hubungan antara sosial kelas dan konteks pendidikan. Kelas sosial mempengaruhi lingkunga fisik sekolah dan akses yang diperleh untuk kesehatan, transportasi umum dan keselamatan fisik (Banks, 2012). Berdasarkan latar belakang di atas, maka penelitian ini akan memfokuskan pada keterhubungan antara materi dan proses pembelajaran dengan kelas sosial dengan batasan rumusan masalah sebagai berikut: 1) Apakah yang dikatakan pihak sekolah tentang ruang lingkup materi pada mata pelajaran Matematika pada tiga sekolah yang berbeda kelas sosial?, 2) Apakah yang dikatakan siswa tentang ruang lingkup materi pada mata pelajaran Matematika pada sekolah yang berbeda kelas sosial?, 3) Bagaimanakah proses pelaksanaan pembelajaran pada mata pelajaran Matematika pada tiga sekolah yang berbeda kelas sosial?

\section{Metode}

Penelitian ini mengunakan metode kualitatif studi kasus dengan mendeskripsikan secara detail yang terjadi pada situasi atau kegiatan tertentu(Agung, 2014). Populasi pada penelitian ini adalah guru dan siswa Sekolah Dasar swasta di bawah payung Yayasan Pelita Harapan yaitu Sekolah Pelita Harapan, Sekolah Dian Harapan dan Sekolah Lentera Harapan. Ketiga sekolah tersebut memiliki visi yang sama yaitu pengetahuan yang sejati, iman di dalam Kristus dan karakter Ilahi(Sugiyono, 2015). Walaupun ketiga sekolah tersebut berada dalam satu payung visi yang sama, ketiga sekolah tersebut memiliki perbedaan dalam hal kelas sosial siswa. Perbandingan kelas ekonomi siswa dari ketiga sekolah tersebut dilakukan dengan membandingkan uang sekolah siswa pada ketiga sekolah tersebut dan jenis pekerjaan orang tua siswa pada ketiga sekolah tersebut. Teknik pengumpulan data pada penelitian ini adalah sebagai berikut:

1) Teknik wawancara:

Melakukan wawancara kepada guru yang mengajar mata pelajaran Matematika dari kelas 2-6 SD. Pertanyaan yang diberikan kepada guru-guru adalah memperdalam pernyataan-pernyataan penting 
yang diucapkan oleh guru-guru pada diskusi grup fokus. Guru yang terlibat pada wawancara dipilih setelah menganalisis hasil dari diskusi grup fokus.

2) Teknik Observasi:

Data dikumpulkan dengan melakukan observasi langsung ke kelas pada tiga sekolah yang berbeda. Observasi kelas dilakukan pada mata pelajaran Matematika.

3) Dokumentasi:

Pengumpulan dokumentasi yang diperlukan seperti silabus, rencana pembelajaran, buku teks yang dipergunakan dan dokumen-dokumen lainnya yang berhubungan dengan mata pelajaran dan proses pembelajaran.

Penelitian ini menggunakan teknik analisis kuantitaif dan kualitatif. Analisis kuantitatif dengan statistik sederhana digunakan pada hasil survey untuk melihat pemahaman guru tentang mata pelajaran Matematika, Sain dan Sosial. Hasil statistik juga dipergunakan untuk melihat jumlah guru yang menggunakan metode pengajaran dan teknik penilaian tertentu pada ketiga mata pelajaran tersebut serta bagaimana media dipergunakan pada ketiga mata pelajaran tersebut.

Teknik analisis kualitatif dipergunakan pada hasil data wawancara, diskusi grup fokus, observasi dan dokumen. Analisis kualitatif pada penelitian ini dilakukan dengan langkah-langkah sebagai berikut: 1) mengubah data dalam bentuk transkrip, 2) mengkategorikan data, 3) mencari pola dan menentukan tematema dari setiap kategori, 4) mencari keterhubungan antara tema, dan 5) penarikan kesimpulan.

\section{Hasil dan Pembahasan}

\section{Sekolah dengan Kelas Sosial Bawah}

\section{Pengetahuan Matematika}

Respon siswa terhadap pertanyaan tentang materi matematika yang dipelajari di sekolah adalah menyebutkan beberapa topik umum yang dipelajari pada pelajaran matematika, seperti penjumlahan, pengurangan, perkalian dan pembagian. Hasil interviu dengan dua orang guru yang mengajar Matematika menunjukkan bahwa Matematika adalah seperangkat fakta yang harus dihapal oleh siswa.

Salah satu contoh respon guru "Misalnya kalau matematika kan cuma bicara caranya berhitung, menjumlah, mengurang, mengali, membagi. Itu aja sebenarnya. Kalau saya, kalau perkalian itu kan sebenarnya harus dihafal. Begitu. Jadi, saya pun nge-treat mereka hafal perkalian. Cuma saya memang nggak treatment khusus di kelas 6 untuk ayo hafal perkalian 1 sampai 10. Cuma masalah-masalah yang memang sesuai konteks mereka di kelas 6 . Misalnya waktu itu saya ajar bilangan pangkat 3 . Jadi cara saya mengajar mereka supaya mereka ingat, saya pakai lagu. Jadi nyanyi mereka. Jadi 13 sampai 153, karena menurut saya itu penting. Seterusnya nanti bisa ajarinn kamu cara cepat, tapi yang penting kamu tahu dulu 13 sampai 153. Pakai lagu. Caranya begitu sih".

\section{Pedagogi Matematika}

Pertanyaan kedua yang diberikan kepada siswa adalah tentang kegiatan pembelajaran matematika yang dialami oleh siswa. Jawaban siswa menujukkan kegiatan pembelajaran yang memang dialami oleh siswa. Contoh respon siswa "Kegiatannya main games. Kita itu ada perosotan dua, terus dibawahnya ada mangkuk, dan misalnya, em..misalnya 3 dimasukkan biji congklaknya, 3 lagi di dalamnya kan sudah ada congkaknya, tinggal kita hitung di dalamnya, jadi enam". Jawaban siswa juga menunjukkan lebih kepada langkah-langkah dalam melakukan operasi perhitungan seperti pengurangan, perkalian dan pembagian. "Kalau pengurangan, kata ibu sih, ga usah..,kalau pengurang bisa juga tujuh diambil dua, lima. Tapi kata ibu, lebih gampangnya, mikirnya, sepuluh. Sebelum sepuluh...kan sepuluh dikurang satu, sepuluh, jarinya sepuluh dikurang satu jadinya sembilan". Hal menarik dari respon siswa tersebut adalah siswa cenderung mengingat dan mematuhi perkataan gurunya. Contoh lainnya adalah "Kegiatannya pernah sih satu kali..setiap grup dikasih nilai, kan ibu bilang jawabannya, eh soalnya, trus kita tulis di buku jawabannya. Kalau yang benar dapat buku poin".

Respon siswa terhadap kegiatan yang dipelajari pada Matematika menunjukkan bahwa perkalian dipelajari dengan menghafal. Siswa berkata: "Kalau perkalian, kan baris. Sebelum masuk kelas dites. Misalnya guru bilang 7x7 berapa. Nanti yang mau masuk kelas jawab". Jawaban guru juga menunjukkan bahwa pedagogi perkalian adalah dengan menghafal dan alasan menghafal adalah karena konsep perkalian merupakan konsep yang baru pertama kali dipelajari oleh siswa kelas tiga SD. Guru berkata "Contohnya perkalian diawal itu kan mereka harus hafal, nah perkalian adalah yang berat untuk siswa kelas 3 karena materi kelas 3 dan 2 itu cukup jomblang. Perkalian baru diajarkan di kelas tiga jadi cukup berat. Jadi menghafalkan perkalian itu menenurut saya cukup berat apalagi anak-anak yang baru naik kelas 3, jadi mereka harus diberi motivasi kenapa kamu dikasih perkalian supaya diperhitungan perkalian selanjutnya lebih mudah jadi harus dikasih seperti itu". 
Selain pedagogi menghafal, jawaban siswa kelas 4, 5 dan 6 menunjukkan bahwa latihan soal merupakan metode pembelajaran yang sering diterapkan oleh guru. Reson siswa kelas 4 "Belajar sama ibu dulu, dijelasin baru latihan soal”. Respon yang sama dari siswa kelas 5 "Kerjain soal latihan”. Respon siswa kelas 6 juga menunjukkan kegiatan pembelajaran cenderung melakukan pengulangan terhadap materimateri sebelumnya. "Oh iya, matematika itu biasanya kita ada yang ulang dari kelas empat lima, trus ada lagi yang di kelas enam seperti kayak pengolahan data, terus ada lagi kayak, mmm..yang pengolahan data itu kayak diagram trus mean, median, modus gitu-gitu". Pedagogi menghafal dan reviu juga merupakan penekanan dari guru kelas 6 dalam belajar matematika oleh karena adanya ujian nasional.

\section{Sekolah dengan Kelas Sosial Menengah}

Pengetahuan Matematika

Hal yang menarik dari respon siswa tentang materi yang siswa pelajari pada pelajaran matematika adalah 4 siswa dari 5 siswa yang diinterviu menjawab "word problem". Respon lainnya adalah menyebutkan beberapa topik umum yang dipelajari pada pelajaran matematika, seperti penjumlahan, pengurangan, perkalian dan pembagian. Semua siswa menggunakan Bahasa Inggris ketika memberikan jawaban tentang materi yang mereka pelajari pada pelajaran Matematika(Nugroho, Putra, Putra, \& Syazali, 2017).

Hasil interviu guru juga menunjukkan bahwa memberikan soal cerita merupakah tipikal pada pembelajaran Matematika di sekolah ini dengan tujuan untuk meningkatkan keterampilan analisis siswa. "Kita kasih issue, masalah, coba di-solve. Pertama, dari issue masalah itu mereka harus bisa mentranslate-nya ke dalam model matematika, lalu di-solve menggunakan ya rumus-rumus ya mereka sudah tahu, trik-triknya. Karena di matematika itu kan banyak jalan. Benar ya? Nggak cuma patokan harus jalan A, itu kan nggak. Yang penting prosedurnya benar dan hasilnya benar. Jadi itu melatih analisis skill mereka juga dan problem solving mereka". Respon lain dari guru tersebut adalah "Di setiap topik itu harus ada word problem-nya".

\section{Pedagogi Matematika}

Hal yang sangat menarik dari jawaban siswa tentang kegiatan pembelajaran yang dialami pada pelajaran Matematika adalah respon siswa kelas 2. Selain menggunakan Bahasa Inggris dalam memberikan jawaban, respon siswa tersebut juga menunjukkan pemahaman konsepnya tentang perkalian yaitu pengulangan berulang. Siswa tersebut berkata "like $5+5+5+5$, like that. Yeah, we keep counting every number." Pemahaman konsep siswa juga terlihat ketika memberi contoh kegiatan yang dipelajari pada topik pecahan. Siswa tersebut berkata "There is a shape and then we like.... we shaded, the one that's color. And then tell what parts are shaded. And then we have to tell are they equal to or not, or what part are not shaded. And we have to like the number fraction. We have to know the sentences so we don't get to stop". Respon siswa kelas 3 tentang kegiatan yang dialami ketika belajar Matematika cenderung mengingat prosedur dalam melakukan perhitungan pecahan. Siswa tersebut juga menggunakan istilah-istilah pecahan yaitu pembilang dan penyebut dengan Bahasa Inggris. Siswa tersebut berkata "Denominator harus disamain dulu. Habis disamain dikali dengan angka yang sama numeratornya. Misalnya yang satu denominatornya 20 yang satunya 4, kan kali 3 sama dengan 12. Misalnya numeratornya 1, satu kali tiga sama dengan tiga".

Respon siswa kelas 4 menunjukkan latihan soal dan tes merupakan kegiatan yang sering dialami oleh siswa. Siswa kelas 5 cenderung menekankan kegiatan kerja kelompok pada pembelajaran Matematika. Siswa tersebut berkata "Waktu disuruh yang geometrical construction, buat tes kita bisa gambar bentuknya benar atau enggak, kita disuruh gambar kayak istana gitu. Habis itu dibagi grup 4 orang, kita disuruh bagi pekerjaannya habis itu selesai semuanya udah digambar bentuknya, dibentuk jadi istana. Tapi beberapa group yang lain juga bikin". Metode latihan soal dan ualngan terlihat sebagai fokus kegiatan pembelajaran matematika pada kelas 6. Respon siswa adalah "Kayak pindahin data jadi diagram, kayak yang bar gram gitu, terus cari debit juga, itu kayak berapa liter permenit. Trus belajar satuan juga, kayak satuan pengukuran, kayak misalnya satuan waktu juga, kayak misalnya satu jam itu 60 menit atau kayak 1 abad itu 100 tahun, belajar gituan. Terus, setelah diajarin kita latihan, terus kita ulangan". Hasil interviu dengan guru kelas 6 juga menujukkan hal yang sama bahwa latihan soal dan reviu ditekankan pada kegiatan pembelajaran pada kelas 6 untuk persiapan ujian nasional.

Hasil interviu dengan guru kelas tiga yang mengajar pelajaran Matematika menunjukkan bahwa pembelajaran perkalian untuk tahap pertama adalah mengajarkan siswa untuk memahami konsep perkalian dengan melibatkan siswa dalam kegiatan pembelajaran yang membangun pemahaman siswa. Guru tersebut menjelaskan "Kalau misalnya kayak multiplication gitu ya, biasanya kita kasih bendanya dulu. Saya bisanya gini, "give me like example of numbers of 2". Coba nanti sediakan sama Miss tiga, tiga, tiga. Saya biasanya sudah kasih jumlah benda tertentu. Bikin group of 3, group of 4 . Nah dari situ nanti 
mereka bisa menarik kesimpulan tuh, oh group of 4 itu berarti ini ya Miss ya, ada 4 bendanya. Nanti saya balik, make me 6 groups. Nah, dari kegiatan tersebut mereka membawa pengertiannya, saya bawa ke jumlahnya, jumlahnya ada berapa ya. Berarti bisa dikatakan oh berarti 2-nya ada 6 kali, itu pasti anak biasanya bisa menimbulkan itu sendiri".

\section{Sekolah dengan Kelas Sosial Atas}

Pengetahuan Matematika

Pertanyaan tentang pelajaran matematika diberikan kepada siswa pada sekolah kelas atas. Setiap siswa memberikan respon yang menarik dan tidak bersifat mekanis. Respon siswa kelas dua cenderung menunjukkan pemahaman konsep siswa tersebut ketika belajar matematika dari pada sekedar menyebutkan materi atau topik yang telah dipelajari siswa tersebut pada pelajaran matematika. Pemahaman konsep tersebut terlihat dari pemahaman pola dari konsep matematika yang siswa tersebut pelajari. Respon siswa tersebut "Greater and less than and plus one (+1) and minus one $(-1)$ and counting of the decade. Counting the decade is just like first 10 then $20,30,40$, right? In the back there is like a zero (0) but in the fromt is just like 1, 2, 3, 4, 5 but just put the zero all the time" Respon menarik lainnya adalah dari dua orang siswa kelas 3 yang diinterviu.

Hasil interviu menunjukkan siswa cenderung memahami matematika sebagai strategi. Contoh respon siswa adalah "splitting and grouping. Jumps strategy, written strategy and mental strategy". Respon lainnya adalah "Jumps strategy, spliiting and about like yeah". Interviu siswa kelas 5 juga menunjukkan hal yang sama bahwa pelajaran Matematika adalah tentang strategi dan keterampilan. "I learnt a new skill today at math class. Yang dimaksud dengan keterampilan adalah strategi yang dipergunakan pada pelajaran Matematika. "Using strategies to learn something new". Respon yang lebih menarik dari siswa kelas 5 lainnya dalah matematika dianggap sebagai penyalahgunaan mental "Math is mental abuse" dan alasan siswa tersebut mengatakan demikian karena Matematika sulit.

Respon siswa kelas 6 menunjukkan 2 hal yang menarik pada pelajaran matematika. Pertama, terdapat penyataan yang terkesan kontradiksi. Siswa tersebut mengatakan pelajaran Matematika bukanlah pelajaran yang siswa tersebut sukai. Namun, siswa tersebut memiliki topik yang disukai pada pelajaran Matematika karena siswa tersebut merasa mudah untuk mengerjakannya ketika di kelas 6 dibanding ketika siswa tersebut di kelas 5. Siswa tersebut berkata "with math, my favorite, study was algebra. Last year we studied algebra. The beginning of the unit I was very confused and it took me like, like 10 minutes to answer the question I don't understand. But now, I could calculate something in algebra in a few seconds and I can know" . Hal kedua yang menarik dari siswa kelas 6 ini adalah pembelajaran matematika menggunakan teknologi digital yaitu Edmodo. Hasil observasi pembelajaran matematika menujukkan bahwa siswa mengerjakan latihan soal matematika menggunkan XL on line yaitu berupa soal-soal latihan Matematika yang dikerjakan secara on line. Selain itu, guru menggunakan Edmodo sebagai website komunikasi pada pelajaran Matematika, seperti pekerjaan rumah yang harus dikrejakan dan informasi-inormasi penting lainnya pada pelajaran Matematika.

Hasil interviu dengan guru menunjukkan bahwa matematika adalah tentang pemahaman konsep. Respon salah satu guru kelas 3 "Yang pasti yah konsep mengenai angka sih, konsep mengenai angka, konsep bagaimana emmm angka itu beraturan. Misalnya tentang numbers yah berarti dari awal kita belajar tentang press value nya, iya kan bagaimana ini nol sampai sembilan ini ada dijitnya. Jadi konsepkonsepnya itu banyak sebenarnya. Konsep penempatan nilai, penempatan ones tens sama hundred-nya sama itu yang harus dimengerti juga".

\section{Pedagogi Matematika}

Hasil interviu dengan guru kelas 3 menunjukkan bahwa kegiatan pembelajaran pada pelajaran matematika memiliki tahapan tertentu. Tahap awal dalam mempelajari konsep baru pada pelajaran matematika adalah tahapan pemahaman. Pada tahap ini guru menuntun siswa untuk memahami konsep tersebut dengan berbagai kegiatan pembelajaran yang bersifat melibatkan siswa dan membuat siswa mengalaminya. Alat-alat pembelajaran yang kongkrit dan kontekstual juga dipergunakan untuk membantu pemahaman siswa. Salah satu respon guru "Saya menggunakan yang kongkrit terlebih dahulu. Setelah barang-barang yang kongkrit, baru ke angka. Kadang-kadang ke picture dulu sih, biasanya pakai gambar, lalu ke angka. Nah itu kan konsepnya yang tadinya mungkin buat mereka abstrak, bagaimana menjadikan itu real buat mereka, kongkrit buat mereka, seperti itu".

Respon lain dari guru kelas 3 "Misalnya dua belas dikali dua, tapi kalau anak-anak dikasi tahu, entar ada dua kelompok. Ini jumlahnya masing-masing tiga, terus ada tiga kelompok, oh lalu... kalau ditotal itu ada sembilan lho gitu, jadi anak-anak tuh ngerti dari basiknya aja. Dari basiknya, jadi untuk ke berikutnya, otak mereka pun udah kegambar. Oh, dua puluh empat kali tiga, oh berarti ada disini tiga cups dan masing-masing cups ada dua puluh empat. Itu totalnya ada berapa yah? Berarti kayak ada gambaran. 
Ketimbang dua dua puluh empat dikali tiga berarti gambarnya itu angka semua dan harus hitung. Itukan lebih susah bayanginnya. Apalagi anak-anak jaman sekarang, mereka yang lebih ke yang hands on visual gitu-gitu".

Tahap kedua dalam pembelajaran matematika adalah tahap mengaplikasikan konsep yang telah dipahami. Pada tahap ini memerlukan kemampuan mengingat dengan cepat strategi-strategi menggunakan konsep yang telah dipelajari. Mengingat strategi penyelesaian matematika bukan merupakan tahap awal pada pembelajaran matematika. Respon dari salah seorang guru "jadi konsep itu berarti kembali ke dasar. Bukan berarti kamu hafalin dua kali tiga sama dengan enam, yah itu kan mati. Kalau konsep kan berarti ada dua two groups of three gitu. Bukan berarti tidak perlu menghafalkan tetapi kita kembali ke konsep. Setelah itu, mereka otomatis, bisa seharusnya menghafalkan. Mmm kayak siswa saya, karena ada konsep lalu dia bisa menyelesaikan masalahnya walaupun mungkin tahapannya lebih lama gitu daripada yang hafal mati gitu kan. Tapikan kalau hafal mati kan bisa juga salah"

Hasil analisis data menunjukkan bahwa siswa pada ketiga sekolah dengan kelas sosial yang berbeda mempelajari konsep perkalian. Namun terdapat perbedaan yang jelas dalam 2 hal. Pertama, pemahaman guru tentang pengetahuan Matematika secara khusus tentang konsep perkalian. Kedua adalah pedagogi yang digunakan oleh guru dalam pembelajaran Matematika. Pemahaman guru tentang pengetahuan Matematika mempengaruhi pedagogi guru tersebut. Pedagogi guru yang diterapkan melalui kegiatan pembelajaran membentuk pemahaman siswa tentang pengetahuan Matematika. Pemahaman guru tentang Matematika kemungkinan dipengaruhi oleh kurikulum yang dipergunakan oleh ketiga sekolah tersebut. Sekolah dengan latar belakang kelas sosial atas menggunakan kurikulum International Baccalaureate (IB). Kurikulum International Baccalaureate adalah kurikulum yang memiliki kerangka pengetahuan, konsep, keterampilan, sikap dan tindakan yang diperlukan oleh siswa untuk memperlengkapi mereka untuk hidup yang sukses pada masa sekarang dan masa depan. Pemahaman konsep menjadi penekanan pada kurikulum ini dan terinformasikan pada seluruh kegiatan pembelajaran.

Sekolah dengan latar belakang kelas menengah dan bawah menggunakan kurikulum yang sama yaitu kurikulum 2013. Pada dasarnya kurikulum ini menekankan pada pemahaman konsep. Pemerintah mengorganisasi kurikulum 2013 sedemikian rupa yang mencakup kompetensi implementasi dan kompetensi ini memerlukan siswa untuk menunjukkan kemampuan berfikir kritis, logis, analitis dan kreatif (Peraturan Menteri Pendidikan dan Kebudayaan Indonesia nomor 24 tahun 2016. Kurikulum Satuan Tingkat Pendidikan (KTSP) yang diterapkan sejak tahun 2006 (yang kemudian diganti dengan kurikulum 2013) juga menekankan pada kemampuan berfikir logis, analitis, kritis dan kreatif sebagai tujuan pembelajaran Matematika. Hal tersebut dimaksudkan oleh karena matematika memaikan peranan yang siknifikan pada dunia teknologi dan modern (Peraturan Menteri Pendidikan Nasional No.22 tahun 2006).

Namun pada kenyataannya pembelajaran Matematika masih bersifat menjelaskan langkah-langkah penggunaan rumus kemudian siswa menyelesaikan soal dengan langkah-langkah yang telah dijelaskan sehingga siswa cenderung menghafalkan langkah-langkah tersebut. Hal ini kemungkinan disebabkan oleh karena kepercayaan guru tentang Matematika masih merupakah seperangkat langkah-langkah pengerjaan soal yang harus diingat dan kepercayaan tersebut mempengaruhi pedagogi yang diterapkan pada pembelajaran Matematika. Raturi \& Boulton-Lewis (2014) menjelaskan bahwa hubungan antara kepercayaan guru dan dosen tentang strategi belajar mereka sendiri dan bagaimana mereka mengajar selalu ada. Dan kepercayaan tersebut dibentuk berdasarkan pengalaman mereka sendiri tentang strategi belajar yang memang bekerja dengan baik untuk mereka dan berdasarkan yang mereka lihat dari teman kerja senior mereka. Kepercayaan tersebut juga dibentuk dari konteks akademik dimana mereka diperkerjakan dan pengalaman mereka sebagai seorang siswa di sekolah dan mahasiswa di universitas.

Terlepas dari kurikulum persamaan kurikulum yang dipergunakan oleh sekolah kelas menengah dan kelas bawah, pedagogi perkalian pada sekolah kelas menengah dan bawah terlihat sangat berbeda. Pedagogi Perkalian pada kelas menengah menekankan pada pemaham konsep perkalian sementara pada kelas bawah menekankan pada menghafal perkalian. Pedagogi matematika pada kelas atas dan pedagogi perkalian pada sekolah kelas menengah mendorong siswa untuk berfikir kritis. Pedagogi berfikir kritis berimplikasi secara sosial dimana siswa dipersiapkan untuk terampil dalam berfikir yang merupakan ketrampilan yang sangat dibutuhkan untuk dapat bertahan hidup pada dunia global yang kompetitif, tidak pasti dan selalu berubah (Peraturan Menteri Pendidikan dan Kebudayaan Indonesia nomor 24 tahun 2016)

Memiliki keterampilan berfikir demikian, siswa setelah lulus sekolah memiliki kesempatan pekerjaan yang lebih baik seperti menjadi menejer dan pekerjaan professional lainnya. Sementara pedagogi Matematika pada sekolah kelas bawah cenderung kepada pedagogi yang menuntun siswa menjadi pendengar yang baik dengan menjelaskan seperangkat langkah-langkah penyelesaian soal. Pedagogi tersebut dengan demikian membuat siswa lebih berfikir mekanik dari pada kreatif. Dengan demikian materi pembelajaran, pedagogi dan penilaian yang dialami oleh siswa selama pendidikan mereka dapat memberikan prediksi tentang status sosial siswa di masa depan. Hill (1999) menuliskan 
dengan tegas bahwa terdapat perbedaan berdasarkan kelas sosial pada sistem pendidikan yang mencakup perbedaan -perbedaan pada metode mengajar, materi kurikulum, pencapaian dan tujuan pendidikan.

Selain itu, penggunaan Bahasa Inggris pada pembelajaran memberikan juga prediksi yang kuat tentang status sosial yang dimiliki siswa di masa yang akan datang. Subkan berargumen bahwa aka nada kesempatan untuk mengakses pengetahuan yang bertumbuh secara cepat karena perkembangna pengetahuan berasal dari Barat yang menggunakan Bahasa Inggris(Subkhan, 2016). Oleh karena itu, mereka yang dapat menguasai Bahasa Inggris kemungkinan dapat bertahan hidup di dunia global yang kompetitif.

\section{Simpulan dan Saran}

Pengetahuan matematika yang diajarkan guru di kelas mempengaruhi pedagogi yang dipergunakan dalam proses pembelajaran. Pedagogi pembelajaran matematika yang dialami oleh siswa berimplikasi secara sosial. Pedagogi dapat membebaskan seseorang dari tingkat kehidupan sosial yang rendah atau sebaliknya, membiarkan seseorang pada tingkat kehidupan sosial tertentu. Pedagogi berfikir kritis pada mata pelajaran matematika dapat membentuk siswa menjadi seorang yang terampil dalam berfikir kritis dan kreatif. Sebaliknya, pedagogi mentransfer informasi pada pembelajaran matematika membentuk siswa menjadi individu yang kurang berfikir namun cenderung mendengarkan.

Keterampilan seorang individu dalam berfikir kritis dan kreatif menjadikan individu tersebut lebih diminati pada pekerjaan-pekerjaan professional yang menjanjikan gaji yang lebih tinggi. Keterampilan berfikir kritis dan kreatif tersebut diperlukan dalam menyelesaikan masalah dan berinovasi. Pedagogi mendengar lebih cenderung menuntun kepada sikap mendengarkan tanpa berfikir. Pekerjaan professional tentu lebih memerlukan orang berfikir kritis daripada sekedar mendengarkan.

Kelas sosial mempengaruhi pengetahuan yang diajarkan dan pedagogi yang dipergunakan guru. Setiap guru hendaknya mencermati pedagogi yang dipergunakannya sehingga dapat menuntun kepada pembebasan siswa dari tingkat hidup sosial yang rendah bukan justru pembiaran pada tingkat kehidupan demikian. Pemahaman matematika dan pedagogi untuk pemahaman kiranya dapat dialami oleh siswa dari kelas sosial bawah.

\section{Daftar Rujukan}

Agung, A. A. G. (2014). Metodologi Penelitian Pendidikan. Malang: Aditya Media Publish.

Anyon, J. (1981). Social Class andnnnn School Knowledge. Curriculum Inquiry, 11(1). https://doi.org/10.2307/1179509

$\mathrm{Au}, \mathrm{W}$. (2012). Critical Curriculum Studies: Education, Consciousness, and the Politics of Knowing. New York: Routledge Taylor and Francis Group.

Banks, J. . (2012). Encyclopedia of Diversity in Education: Social Class and Education. Los Angeles: Sage reference.

Hamalik, O. (2009). Kurikulum dan Pembelajaran. Jakarta: Bumi Aksara.

Hill, D. (1999). Social Class and Education. In D. mathheson \& I. Grosvenor (Eds.). London: David Fulton publishers.

Huebner, E. S., dan Diener, C. (2008). Research on Life Satisfaction of Children and Youth: Implication for the Delivery of School-Related Services. In Eid, M., and Larsen, J.R. (Eds). New York: The Guilford Press.

Nugroho, A. A., Putra, R. W. Y., Putra, F. G., \& Syazali, M. (2017). Pengembangan Blog Sebagai Media Pembelajaran Matematika. Al-Jabar: Jurnal Pendidikan Matematika. https://doi.org/10.24042/ajpm.v8i2.2028

Peraturan Menteri Pendidikan dan Kebudayaan Indonesia nomor 24 tahun 2016. (n.d.).

Peraturan Pemerintah Republik Indonesia nomor 19 tahun 2005 tentang Standar Pendidikan Nasional. (n.d.).

Raturi, S., \& Boulton-Lewis, G. (2014). Shaping lecturers' beliefs about teaching and learning in higher education in the Pacific. Informit, 24(1).

Rusman. (2009). Manajemen Kurikulum. Jakarta: Rajawali Pers.

Sanjaya, W. (2008). Kurikulum dan Pembelajaran: Teori dan Praktik Pengembangan Kurikulum Tingkat 
Satuan Pendidikan (KTSP). Rawangun: Kencana Predana Media Group.

Subkhan, E. (2016). Pendidikan Kritis. Yogyakarta: Ar-Ruzz Media.

Sugiyono. (2015). Metode Penelitian Pendidikan (Pendekatan Kuantitatif, kualitatif, dan R\&D). Bandung: Alfabeta. 